\title{
Self-monitoring dan Kemampuan Verbal Terhadap Perilaku Berbohong
}

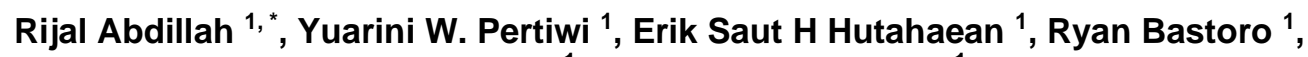 \\ Rizki Amalia P Putri ${ }^{1}$, Tiara Anggita Perdini ${ }^{1}$ \\ ${ }^{1}$ Fakultas Ilmu Psikologi; Universitas Bhayangkara Jakarta Raya; Jl. Raya Perjuangan, \\ Marga Mulya, Bekasi Utara, Jawa Barat 17121. Telp: 021-88955882, 889955883; e-mail: \\ rijal.abdillah@dsn.ubharajaya.ac.id, yuarini.wp@dsn.ubharajaya.ac.id, \\ erik.saut@dsn.ubharajaya.ac.id, bastoro.ryan@gmail.com, kikiprynto95@gmail.com, \\ tiaraanggitaperdini@gmail.com
}

*Korespondensi: e-mail: erik.saut@dsn.ubharajaya.ac.id

\begin{abstract}
Lies are carried out by individuals in many of their daily activities, the impact of lying is detrimental to others, and the perpetrators. The results of previous studies have explained that this happens because the perpetrator of lying can monitor his appearance so that it is difficult for the victim to see it as a lie. The most difficulty in recognizing lies is identifying indicators of lying. Therefore it is important to be able to identify indicators of lying behavior. Through two series of studies, this study aims to conduct an analysis of lying, through survey research and inlaboratory research. There were 74 subjects in the survey, and 60 people were involved to be the subject of experimental research. With details of 20 people as the lying group, 20 people as the honest group and 20 people as the neutral group. The results of the survey study found that self-monitoring is related to lying behavior, and self-monitoring also has a direct effect on lying behavior. Conversely, verbal ability is not related to lying. In the experimental study, it was found that the heart rate was different between the three experimental groups. Similar to the sound amplification ( $d b)$ there was a significant difference between the three experimental groups, but the analysis of the sound wave pattern showed no difference. The results of the analysis of the response reactions and eye movements were not different. The empirical facts of this study can be used to identify indicators of lying behavior.
\end{abstract}

Keyword: self-monitoring, verbal ability, heart rate, eye movements, and lying behavior

\begin{abstract}
Abstrak
Berbohong dilakukan oleh individu pada banyak di setiap aktivasnya sehari-hari, dampak dari perilaku berbohong merugikan orang lain, dan diri pelakunya. Hasil studi terdahulu menerangkan hal itu dapat terjadi karena pelaku berbohong dapat memantau tampilan keadaan dirinya sehingga sulit di lihat oleh korbannya sebagai kebohongan. Kesulitan terberat dalam mengenali kebohongan di dalam aktivas sehari-hari adalah mengenali indikator-indikator yang menjadi bagian dari perilaku berbohong. Berupa kemampuan verbal, reaksi memberikan jawaban, ekspresi wajah, denyut jantung, suara yang dikeluarkan. Oleh karenanya penting untuk dapat mengenali indikator tentang perilaku berbohong. Melalui dua rangkaian studi penelitian ini berupaya untuk melakukan analisis mengenai perilaku berbohong, secara penelitian survei dan penelitian di dalam laboratorium. Sebanyak 74 subjek dilibatkan di dalam proses studi survei. Kemudian sebanyak 60 orang dilibatkan untuk menjadi subjek penelitian eksperimen. Dengan rincian 20 orang untuk kelompok berbohong, 20 orang untuk kelompok jujur dan 20 orang untuk kelompok netral (bebas memilih bohong atau jujur). Hasil studi survei mendapatkan fakta bahwa self-monitoring berhubungan dengan perilaku berbohong, dan selfmonitoring juga berpengaruh secara langsung terhadap perilaku berbohong. Sebaliknya kemampuan verbal tidak berhubungan dengan perilaku berbohong. Pada studi eksperimen didapatkan hasil bahwa denyut jantung terjadi perbedaan diantara tiga kelompok eksperimen.
\end{abstract}


Begitupula dengan amplifikasi suara (db) terjadi perbedaan yang signifikan diantara ketiga kelompok eksperimen, akan tetapi analisis terhadap pola gelombang suara tidak menunjukkan adanya perbedaan. Begitu juga hasil analisis terhadap reaksi menjawab dan gerakan mata keduanya tidak didapatkan adanya perbedaan. Fakta empiris penelitian ini kiranya dapat dimanfaatkan untuk mengenal mengenai indikator perilaku berbohong.

Kata Kunci: self-monitoring, kemampuan verbal, denyut jantung, gerak mata, dan perilaku berbohong

\section{Pendahuluan}

Berbohong merupakan salah satu perilaku yang acap kali dilakukan oleh individu untuk menghindari situasi tertentu. Bahkan dalam sebuah penelitian dikatakan bahwa perilaku berbohong sudah dilakukan sejak usia dini (Talwar \& Lee, 2008). Dalam sehari individu pasti melakukan kebohongan walaupun hanya satu kali, baik disadari atau tidak disadari (Walczyk et al., 2005). Dalam kenyataannya, tidak ada satupun individu yang merasa senang dibohongi walaupun hanya kebohongan kecil. Perilaku berbohong menyebabkan individu yang dibohongi merasa dirugikan dan mendapatkan dampak tertentu, begitu pula dengan individu yang melakukan kebohongan, hanya saja pelaku yang melakukan kebohongan tidak secara langsung merasakan dampak kerugiannya. Salah satu kerugian yang bisa dihasilkan dari perilaku berbohong terhadap orang yang dibohongi yaitu selalu merasa curiga terhadap orang lain. Individu yang sering dibohongi akan kehilangan rasa percayanya terhadap orang lain dan tidak akan mudah untuk kembali percaya. Lalu kerugian perilaku berbohong terhadap individu yang melakukan kebohongan yaitu selalu merasa gelisah dan takut jika kebohongannya akan ketahuan. Individu yang sering melakukan kebohongan juga perlahan akan kehilangan kepercayaan dari orang lain.

Perilaku berbohong tidak muncul secara tiba-tiba, melainkan karena ada beberapa faktor tertentu yang menjadi penyebab. Beberapa faktor yang menyebabkan perilaku berbohong terkait dengan pendekatan komunikasi yaitu kemampuan verbal dan kemampuan memperhatikan diri dalam memberikan reaksi (Ellis \& Beattie, 2017) .Kemampuan verbal adalah kemampuan potensial yang dimiliki individu dalam bidang Bahasa. Kemampuan memperhatikan diri dalam memberikan reaksi atau bisa disebut self-monitoring adalah kecenderungan individu dalam mengatur perilaku diri sendiri untuk disesuaikan dengan tuntutan-tuntutan situasi sosial. Perilaku berbohong sulit untuk dilihat dan ditemukan pada individu, karena beberapa individu memiliki kemampuan untuk memantau reaksi dirinya sehingga petunjuk gejala perilaku berbohong dapat disembunyikan dengan baik. Hal tersebut juga membuat korban yang dibohongi tidak sadar bahwa dirinya sedang dibohongi. Selfmonitoring memiliki komponen-komponen yang dikemukakan oleh (Snyder, Mark, 1974), komponen tersebut terdiri dari fokus terhadap perilaku sosial yang pantas, perhatian terhadap perbandingan informasi sosial, kemampuan untuk mengontrol atau memodifikasi tampilan diri, mampu menggunakan kemampuan di situasi yang berbeda dan pertukaran situasi sosial yang bervariasi. Kemampuan verbal ternyata juga turut diikutsertakan dalam proses perilaku berbohong (Zuckerman \& Driver, 1985). Hal itu dapat diperhatikan melalui pernyataanpernyataan yang bertujuan melakukan penyangkalan, yang didasarkan kepada pertimbangan moralitas sosial (Talwar \& Lee, 2008).

Melalui hasil studi yang dijelaskan dari sudut pandang biopsikologi, dijelaskan bahwa perilaku berbohong memiliki beberapa gejala yang dapat ditemukan seperti reaksi wajah yang bisa dilihat dari gerakan mata (Borza, Itu, \& Danescu, 2018) detak jantung, serta kecepatan respon dalam memberikan jawaban (Meijer, Verschuere, Gamer, Merckelbach, \& Ben-Shakhar, 2016). Detak jantung dapat menjadi prediktor dalam melakukan kebohongan (Duran, Tapiero, \& Michael, 2018). Detak jantung dapat digunakan untuk mengetahui emosi seseorang, termasuk ketika seseorang merasa tenang, gelisah, dan takut (Critchley \& Garfinkel, 2017). Sejak lama sudah ada alat yang digunakan oleh kalangan terbatas (yang memiliki kompetensi khusus), yaitu polygraph. Alat ini digunakan sebagai alat bantu untuk mendeteksi kebohongan (JR, 2003). Basis alat ini menggunakan grafik gelombang detak jantung (Nelson, 2015). Namun ada juga riset lainnya yang mengemukakan mengenai katerbatasan penggunaan alat tersebut, yaitu digunakan untuk pihak-pihak tertentu yang memiliki kompetensi saja (Saxe \& Ben-Shakhar, 
1999). Orang-orang awam yang akan memulai penelitian kebohongan dengan pendekatan denyut jantung sangat sulit untuk bisa melakukannya, karena harus mendapatkan pelatihan mengenai alat tersebut. Studi mengenai suara juga diungkap dalam penelitian terdahulu, fokusnya kepada bunyi suara yang dikeluarkan bersamaan dengan keluarnya ucapan saat berbohong.

Peneltian perilaku berbohong juga pernah dianalisis menggunakan pendekatan gerakan mata. Studi terdahulu menggunakan aplikasi eye tracker, fokus penelitian tersebut ditujukan kepada arah tatapan mata (gaze) (Sullivan, Campbell, Hutton, \& Ruffman, 2017). Aplikasi ini masih sangat terbatas dan membutuhkan biaya yang sangat besar untuk digunakan oleh orang-orang yang ingin melakukan penelitian tetapi hanya memiliki pemahaman dasar secara teori mengenai gerakan mata dan perilaku berbohong. Nada suara juga diperhatikan di dalam penelitian studi perilaku berbohong, salah satu penelitian yang pernah ada dilakukan dengan asumsi bahwa nada suara adalah sesuatu yang paling sulit dikendalikan dalam keadaan dimana seseorang muncul kecemsasan di dalam dirinya saat berkata bohong (Villar, Arciuli, \& Paterson, 2013). Indikator perilaku berbohong juga dapat dilihat melalui reaction time, berupa analisis mengenai panjangnya waktu dibutuhkan oleh pelaku untuk memberikan jawaban yang tidak benar (Suchotzki, Verschuere, Bockstaele, Ben-Shakhar, \& Crombez, 2017). Riset tersebut didasarkan kepada prinsip-prinsip investigasi nasional yang baku (Meijer et al., 2016).

Merujuk kepada penelitian terdahulu, dimana didapatkan banyak keterbatasan bagi peneliti pemula yang tertarik melakukan kajian tentang indikator perilaku berbohong. Dimana alat dan aplikasi canggih sangat sulit untuk dapat diakses untuk melakukan penelitian. Karenanya penelitian ini berusaha untuk menggali indikator-indikator penting yang terkait dengan perilaku berbohong dengan menggunakan peralatan dan perlengkapan yang lebih mudah dijangkau untuk peneliti-peneliti pemula, yaitu peralatan yang sangat sederhana.

\section{Metode Penelitian}

Penelitian ini dilakukan melalui dua pendekatan studi, yaitu penelitian survey dan penelitian eksperimen di dalam laboratorium. Studi survey dilakukan dengan melibatkan subjek sebanyak 74 mahasiswa, dengan rentangan usia berada pada rentangan dewasa. Subjek penelitian dipilih menggunakan pendekatan convinince sampling, subjek dilibatkan berdasarkan kesediaannya untuk menjadi responden penelitian. berdasarkan kesediaannya. Hal ini dilakukan mengingat saat proses pengambilan data sedang berlangsung situasi pandemic covid-19. Data penelitian survey diperoleh dengan memberikan skala penelitian dan alat ukur kemampuan verbal langsung kepada subjek penelitian. Adapaun skala yang digunakan adalah skala self-monitoring, dan skala perilaku berbohong. Sebelum dijadikan sebagai alat pengumpul data skala self-monitoring dan skala perilaku berbohong diuji daya diskriminasinya, untuk melihat konsistensi dan keakuratan butir-butir pengukuran. Sedangkan kemampuan verbal menggunakan alat WBIS, data dari alat ini yang digunakan adalah weight score. Teknik analisis yang digunakan pada studi survey adalah teknik korelasi dan regresi sederhana. Analisi pertama dilakukan adalah menguji kelayakan variabel self-monitoring dan kemampuan verbal untuk dijadikan sebagai variabel bebas. Uji regresi dilakukan untuk melihat besarnya pengaruh yang diberikan variabel terhadap variabel terikat.

Lalu dari 74 sebanyak 60 subjek kemudian diikutkan kedalam proses studi eksperimen, dipilih berdasarkan kesediaan dari subjek. Dalam studi eksperimen ini, subjek penelitian dibagi kedalam tiga kelompok ekspeeriment yaitu kelompok berbohong, kelompok jujur dan kelompok netral (bebas memilih, ingin jujur atau bohong), dimana masing-masing kelompok terdapat 20 subjek. Perlakuan terhadap subjek didasarkan kepada pembagian kelompoknya. Artinya jika subjek masuk dalam kelompok berbohong, maka subjek diminta untuk memberikan jawaban yang tidak benar. Jika subjek masuk ke dalam kelompok jujur, kepadanya diminta untuk memberikan jawaban yang benar. Kelompok yang netral diminta untuk memberikan jawaban yang bebas sesuai pilihannya sendiri, jujur atau bohong ditentukan sendiri oleh subjek. 
Tabel 1. Gambaran Analisis Data Eksperimen

\begin{tabular}{lcccc}
\hline Kelompok & Uji Heart Rate & $\begin{array}{c}\text { Uji Gerakan } \\
\text { Mata }\end{array}$ & Uji Suara & $\begin{array}{c}\text { Uji Reaction } \\
\text { Time }\end{array}$ \\
\hline Bohong & $\begin{array}{c}\text { Komparasi tiga } \\
\text { kelompok }\end{array}$ & $\begin{array}{c}\text { Komparasi tiga } \\
\text { kelompok }\end{array}$ & $\begin{array}{c}\text { Komparasi tiga } \\
\text { kelompok }\end{array}$ & $\begin{array}{c}\text { Komparasi tiga } \\
\text { kelompok }\end{array}$ \\
Jujur & & & & \\
Netral & & &
\end{tabular}

Eksperimen dilakukan secara sederhana, dengan menggunakan permainan matematika (menyimpan angka) dimana eksperimenter sudah memiliki jawaban yang sebenarnya. Selama proses permainan matematika pengamatan dilakukan kepada subjek dengan bantuan visual di layar komputer.

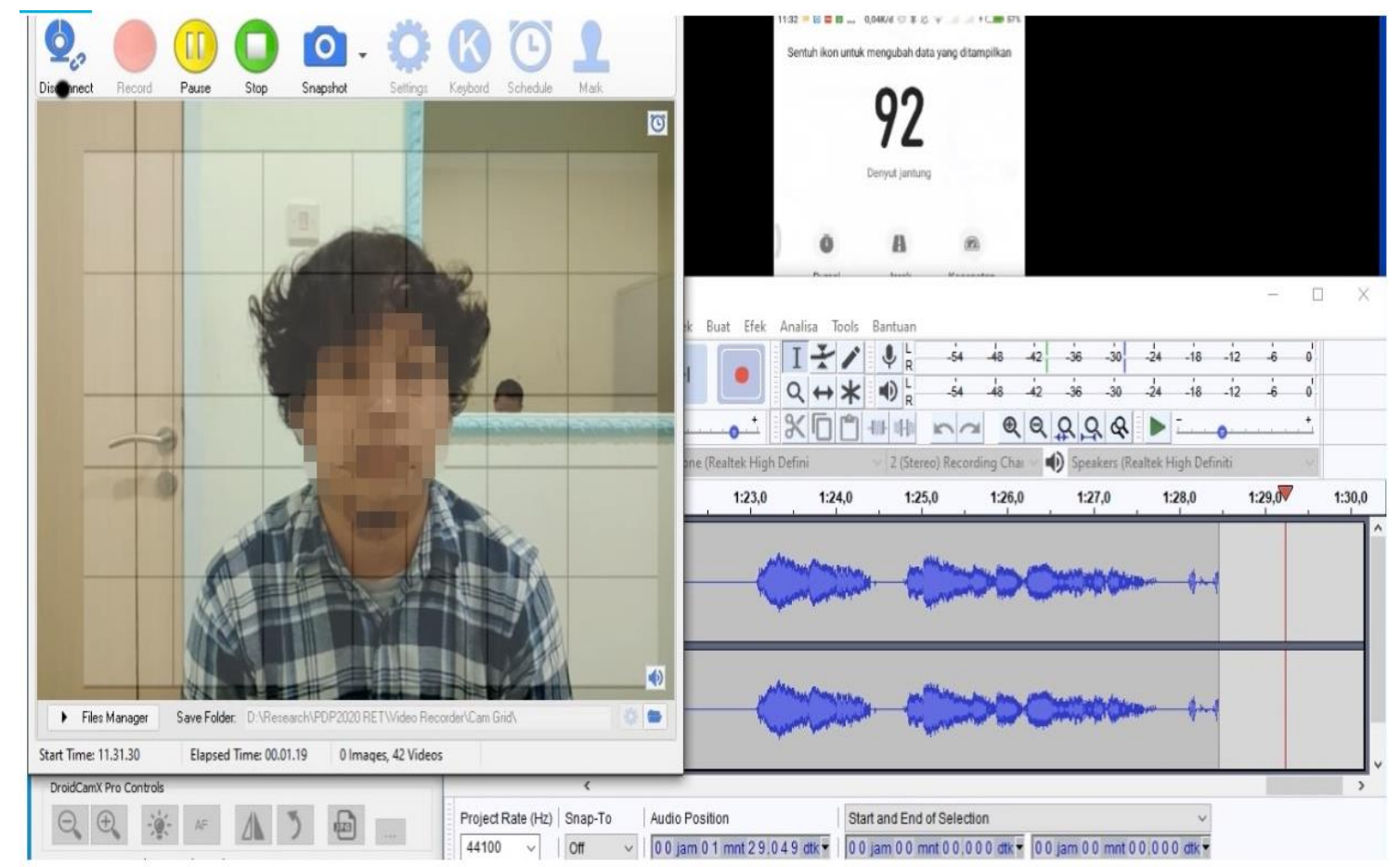

Sumber: Hasil Penelitian (2020)

Gambar 1. Tampilan (visual) layar computer alat ukur

Adapun pengamatan dilakukan dengan perekaman pada visual layar komputer. Pengamatan dilakukan terhadap denyut jantung, reaction time memberikan jawaban, gerakan mata dan suara yang dikeluarkan subjek saat memberikan jawaban. Pengamatan dilakukan pada saat subjek memberikan jawaban atas pertanyaan eksperimenter. Denyut jantung direkam dengan menggunakan alat wrist band, suara menggunakan aplikasi suara auda, gerakan mata menggunakan 9 grid kamera, reaction time menggunakan seting waktu yang terdapat pada aplikasi kamera. Data yang diperoleh dari penelitian eksperimen ini dianalisis dengan menggunakan uji komparasi tiga kelompok. Dimana denyut jantung, gerakan mata, suara, dan reaction time diuji tingkat perbedaannya terhadap tiga kelompok eksperimen (bohong, jujur, dan netral). 


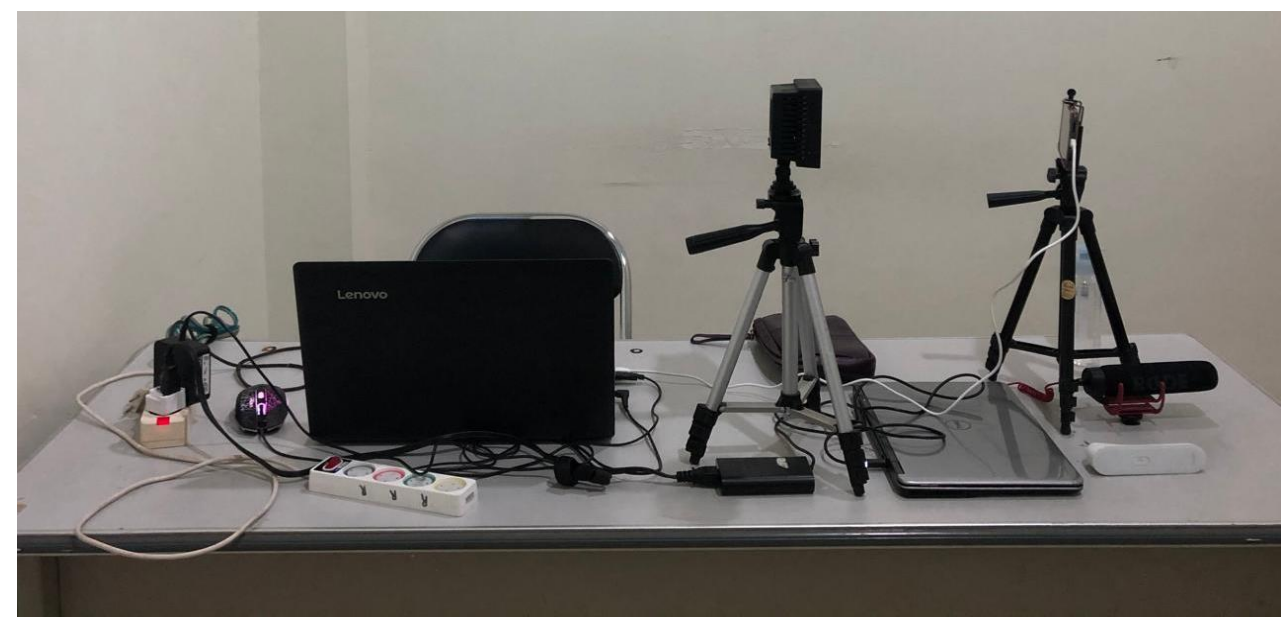

Sumber: Hasil Penelitian (2020)

Gambar 2. Alat Ukur (Hardware) Melalui Visual Komputer

\section{Hasi dan Pembahasan}

\subsection{Uji Coba Alat Pengumpul Data}

Alat pengumpulan data yang digunakan dalam penelitian ini berupa skala selfmonitoring dan perilaku berbohong, sedangkan kemampuan verbal diukur menggunakan alat tes psikologi verbal scale (WBIS). Dalam penelitian ini, uji coba butir-butir skala penelitian (selfmonitoring dan perilaku berbohong) dilakukan untuk melihat koefisien korelasi dan koefisien alpha setiap butir yang ada. Hal tersebut digunakan untuk menentukan apakah setiap butir yang digunakan untuk mengukur variabel dianggap layak dijadikan sebagai alat ukur penelitian. Nilai koefisien korelasi dan koefisien alpha dianalisis melalui uji daya diskriminasi item (Azwar, 2017) untuk menggugurkan butir-butir yang nilai korelasi dan alphanya rendah. Berikut dapat dilihat pada tabel.1 adalah hasil analisis uji coba dengan menggunakan uji daya diskriminasi item.

Tabel 2. Uji Daya Diskriminasi Item Pengumpul Data

\begin{tabular}{cccccc}
\hline $\begin{array}{c}\text { Alat Skala } \\
\text { Pengukuran }\end{array}$ & $\begin{array}{c}\text { Koefisien } \\
\text { Korelasi }\end{array}$ & $\begin{array}{c}\text { Koefisien } \\
\text { Alpha }\end{array}$ & $\begin{array}{c}\text { Butir Uji } \\
\text { Coba }\end{array}$ & $\begin{array}{c}\text { Butir } \\
\text { Gugur }\end{array}$ & $\begin{array}{c}\text { Butir } \\
\text { Layak }\end{array}$ \\
\hline $\begin{array}{c}\text { Self-monitoring } \\
\text { Perilaku }\end{array}$ & $0,380-0,699$ & 0,846 & 11 & 0 & 11 \\
berbohong & $0,482-0,760$ & 0,895 & 11 & 0 & 11 \\
\hline
\end{tabular}

Sumber: Hasil Pengolahan Data (2020)

Hasil dari uji daya diskriminasi item pada kedua variabel menghasilkan 0 item yang gugur, dan item yang tersedia tetap berjumlah 11. Adapun nilai koefisien korelasi pada variabel self-monitoring sebesar 0,380-0,699 dan pada variabel perilaku berbohong sebesar 0,482 0,760 . Selain nilai koefisien korelasi, ada juga nilai koefisien alpha, hasilnya yaitu nilai koefisien alpha pada self-monitoring sebesar 0,846 dan pada perilaku berbohong sebesar 0,895 menandakan bahwa kedua variabel reliabel. Selanjutnya item-item yang tersedia dan layak, disusun menjadi alat pengumpulan data penelitian, yang kemudian akan dilanjutkan pada proses pengumpulan data.

\subsection{Analisis Deskriptif Berdasarkan Data Survey}

Penelitian ini melakukan kajian data deskriptif sederhana, hal ini dilakukan untuk mendapatkan gambaran pendukung untuk dapat memahami fenomena perilaku berbohong. Adapun kajian deskriptifnya difokuskan kepada jenis kelamin, tentu saja dilihat melalui tiga variabel penelitian (self-monitoring, kemampuan verbal dan perilaku berbohong). Hasil deskriptif ini diperoleh melalui kajian survey, menggunakan kuesioner. Ketiga variabel tersebut dianalisis berdasarkan kelompok jenis kelamin (dapat lihat pada tabel 3). 
Tabel 3. Data Deskriptif dan Komparasi Rerata

\begin{tabular}{ccccc}
\hline & & \multicolumn{2}{c}{ Jenis Kelamin } & \multirow{2}{*}{ Signifikansi } \\
\hline SM & Frekuensi & 26 & $\mathbf{P}$ & 0 \\
& Rerata & 0,06 & 48,11 & 0,451 \\
KV & Frekuensi & 26 & 48 & 0 \\
& Rerata & 34,08 & 39,35 & 0,313 \\
PB & Frekuensi & 26 & 48 & \multirow{2}{*}{0,133} \\
\hline
\end{tabular}

Sumber: Hasil Pengolahan Data (2020)

Tabel 3 memperlihatkan bahwa sebaran kelompok jenis kelamin laki-laki terdapat 26 subjek, dan untuk sebaran subjek perempuan jumlahnya 48 subjek, dari total subjek sebanyak 74 subjek penelitian. Hasil yang diperoleh dari analisis data terhadap variabel self-monitoring didapatkan bahwa nilai rerata kelompok laki-laki lebih besar dari nilai rerata kelompok perempuan $(40,06>36,11)$. Selanjutnya hasil yang diperoleh dari analisis data terhadap variabel Kemampuan Verbal didapatkan bahwa nilai rerata kelompok laki-laki lebih kecil dari nilai rerata pada kelompok perempuan $(34,08<39,35)$. Hasil ini sejalan dengan penelitian sebelumnya (Shibley \& Marcia, 1988). Kemudian hasil yang diperoleh dari analisis data pada variabel perilaku berbohong mendapatkann bahwa nilai rerata kelompok laki-laki lebih besar daripada nilai rerata pada kelompok perempuan $(42,60>34,74)$. Temuan ini mendapatkan hasil yang sama dengan penelitian sebelumnya (Dreber \& Johannesson, 2008). Perempuan memiliki perilaku berbohong lebih sedikit karena perempuan lebih altruistik dan kurang memiliki keinginan untuk mengambil resiko, selain itu perempuan kurang memiliki jiwa kompetitif (Croson \& Gneezy, 2009).

Analisis juga dilakukan untuk mendapatkan tingkat perbedaan pada ketiga variabel berdasarkan kelompok jenis kelamin. Hasil analisis komparasi pada variabel self-monitoring mendapatkan tidak terjadi perbedaaan self-monitoring pada kelompok laki-laki dan perempuan $(\mathrm{Sig}=0,451>0,05)$. Penelitian sebelumnya juga menjelaskan bahwa self-monitoring laki-laki dan perempuan seimbang (Flynn \& Ames, 2006). Ada pun temuan dari penelitian lain yang menguatkan temuan ini, variabel self-monitoring pada laki-laki dan perempuan tidak memiliki perbedaan (Sharma \& Bewes, 2011). Begitu juga sama halnya dengan hasil analisis komparasi terhadap variabel perilaku berbohong, tidak terjadi perbedaan $(\mathrm{Sig}=0,133>0,05)$. Sejalan dengan hasil penelitian yang mengemukakan bahwa perilaku berbohong antara laki-laki dan perempuan tidak berbeda (Abouelenien, Pérez-Rosas, Zhao, Mihalcea, \& Burzo, 2017). Kemudian Hal yang sama juga terjadi pada variabel kemampuan verbal, karena tidak terjadi perbedaan antara laki-laki dan perempuan $(\mathrm{Sig}=0,313>0,05)$. Hal ini disebabkan karena keadaan kemampuan verbal pada subjek dalam penelitian ini berada pada kategori yang sama (tidak tinggi).

\subsection{Uji Normalitas Berdasarkan Data Survey}

Uji normalitas perlu dilakukan untuk melihat dan menentukan teknik analisis data selanjutnya, yaitu apakah menggunakan analisis uji parametrik atau analisis uji non-parametrik. Normalitas digunakan untuk melihat gambaran sebaran data skor dari seluruh subjek penelitian. Hasil uji normalitas yang diperoleh dari 74 subjek penelitian memperlihatkan terjadinya sebaran data yang tidak terdistribusi normal. Hasil uji normalitas dapat dilihat pada tabel.3

Tabel 4. Hasil Uji Normalitas Studi Survey

\begin{tabular}{lcc}
\multicolumn{3}{l}{ Tabel 4. Hasil Uji Normalitas Studi Survey } \\
\hline Variabel & df & Sig \\
\hline Self-Monitoring & & 0,006 \\
Kemampuan Verbal & \multirow{2}{*}{74} & 0,200 \\
Perilaku Berbohong & & 0,009 \\
\hline
\end{tabular}

Sumber: Hasil Pengolahan Data (2020) 
Berdasarkan hasil uji normalitas yang telah dilakukan terhadao 74 subjek diperoleh nilai signifikansi pada variabel self-monitoring 0,006 (tidak terdistribusi normal), pada variabel kemampuan verbal 0,200 (terdistribusi normal), dan pada variabel perilaku berbohong sebesar 0,009 (tidak terdistribusi normal). Sebaran data penelitian yang terdistribusi normal hanya kemampuan verbal, dan dua yang lainnya mengindikasikan sebaran data yang tidak terdistribusi normal. Berdasarkan hasil tersebut maka selanjutnya teknik analisis yang digunakan adalah teknik statistic non-parametrik, teknik ini dipilih dengan alasan bahwa analisis selanjutnya tidak memperhatikan sebaran data yang normal. Hal ini merupakan syarat untuk menggunakan statistic parametric sebaran data harus terdistribusi normal (Marshall \& Samuels, 2017).

\subsection{Analisis Korelasional dan Regresi}

Secara umum analisis korelasi dilakukan untuk melihat kaitan yang terjadi antara dua variabel bebas (self-monitoring dan kemampuan verbal) dengan perilaku berbohong. Namun demikian kajian analisis korelasional tidak hanya dilakukan untuk melihat hubungan yang terjadi pada setiap variabel, tetapi kajian dilakukan untuk menentukan penempatan variabel penelitian. Dalam hal ini untuk menentukan sebagai variabel bebas, terikat, dan mungkin menjadi variabel mediator atau moderator. Selanjutnya analisis uji korelasional juga dilakukan untuk menambah kedalaman analisis, misalnya sebagai dasar untuk melanjutkan analisis kepada analisis regresi.

Tabel 5. Korelasi dan Pengaruh Langsung

\begin{tabular}{ccccccc}
\hline Variabel & $\begin{array}{c}\text { Koefisien } \\
\text { korelasi }\end{array}$ & $\begin{array}{c}\text { R2 } \\
\text { SM }\end{array}$ & Constanta & $\begin{array}{c}\text { Koefisien } \\
\text { korelasi }\end{array}$ & $\mathbf{R}^{2}$ & Constanta \\
\hline SM & - & & - & $\mathbf{0 , 2 1 8}^{*}$ & $\mathbf{0 , 0 7 7}$ & 0,273 \\
KV & 0,114 & & - & 0,020 & - & - \\
PB & $\mathbf{0 , 2 1 8 ^ { * }}$ & $\mathbf{0 , 0 7 7 ^ { * }}$ & 0,273 & - & - & - \\
SM-KV & - & - & - & - & 0,075 & $-0,004$ \\
\hline
\end{tabular}

Sumber: Hasil Pengolahan Data (2020)

Tabel 5 memperlihatkan bahwa variabel self-monitoring tidak memiliki hubungan dengan variabel kemampuan verbal. Dilihat dari nilai koefisien korelasi yang tergolong rendah $(0,114)$. Hasil ini menjadikan self-monitoring dan kemampuan verbal sama-sama menjadi variabel bebas, dan selanjutnya diuji keterkaitannya dengan variabel perilaku berbohong. Variabel self-monitoring dengan variabel perilaku berbohong terbukti memiliki hubungan yang signifikan, dengan nilai koefisien korelasi 0,218 . Hal ini sejalan dengan penelitian yang pernah ada, yang mendapatkan bahwa self-monitoring berhubungan secara positif dengan berbohong (Hogue, Levashina, \& Hang, 2016). Menurut penelitian sebelumnya, individu yang akan melakukan kebohongan sebelumnya pasti melibatkan self-monitoring dan juga mengadaptasi komunikasi (Burgoon, Buller, \& Floyd, 2001). Individu sebelum berbohong akan melakukan self monitoring, hal ini dilakukan agar individu tersebut dapat meningkatkan kepercayaan diri saat berbohong, agar kebohongan tersebut tidak terlihat (Burgoon et al., 2001).

Variabel self-monitoring dan variabel perilaku berbohong ditemukan juga memiliki pengaruh yang signifikan dengan nilai $R^{2}$ sebesar 0,077 , yang artinya variabel self-monitoring mempengaruhi variabel perilaku berbohong sebanyak $7,7 \%$, sedangkan nilai konstantanya sebesar 0,273, yang artinya setiap kenaikan satu tingkat self-monitoring akan menaikan perilaku berbohong sebesar $27,3 \%$. Lalu hasil analisa dari variabel kemampuan verbal dengan variabel perilaku berbohong memperlihatkan tidak ada hubungan antara kedua variabel. Dilihat dari nilai koefisien korelasi sebesar 0,020 artinya tidak terjadi keterkaitan. Kemudian variabel self-monitoring dan variabel kemampuan verbal bersama-sama diuji pengaruhnya terhadap variabel perilaku berbohong. Hasilnya menunjukan bahwa self-monitoring dan kemampuan verbal bersama-sama dapat memberikan pengaruh terhadap perilaku berbohong dengan kontibusi sebesar $7,5 \%$. Hasil ini mengindikasikan bahwa dalam perpaduan keduanya dapat memberikan pengaruh terhadap perilaku berbohong, bentuknya dapat berupa pemantauan verbal (Schiller, 2005). 


\subsection{Uji Normalitas Berdasarkan Data Eksperimen}

Sama halnya dengan uji normalitas yang dilakukan pada studi survei. Studi selanjutnya pada hasil eksperimen juga dilakukan uji normalitas dikaji guna menentukan teknik analisis selanjutnya, apakah menggunakan analisis statistik parametrik atau non-parametrik. Data uji normalitas yang didapat berdasarkan subjek yang diikutsertakan ke dalam studi eksperimen berasal dari skor yang diperoleh 60 subjek. Uji normalitas pada studi eksperimen dapat dilihat di tabel 6.

Tabel 6. Hasil Uji Normalitas Studi Eksperimen

\begin{tabular}{ccc}
\hline Variabel & df & Sig \\
\cline { 2 - 3 } Self-Monitoring & \multirow{2}{*}{60} & 0,010 \\
Kemampuan Verbal & 60,055 \\
Perilaku Berbohong & & 0,200 \\
\hline Sumber: Hasil Pengolahan Data (2020) & &
\end{tabular}

Tabel 6 menunjukan hasil uji normalitas pada studi eksperimen. Hasil uji normalitas dilakukan kepada tiga variabel yaitu variabel self-monitoring, kemampuan verbal dan perilaku berbohong. Uji normalitas pada self-monitoring didapat nilai signifikan sebesar 0,010 . Pada variabel kemampuan verbal didapati hasil uji normalitas sebesar 0,055. Kemudian pada variabel perilaku berbohong didapati nilai signifikan 0,200. Dari hasil tersebut dapat disimpulkan bahwa variabel tidak terdistribusi normal, sehingga analisis data selanjutnya memakai uji nonparametrik (Marshall \& Samuels, 2017).

\subsection{Analisis Uji Perbedaan (Denyut Jantung, Suara, Reaksi Waktu Menjawab, Gerak Mata)}

Kajian penelitian eksperimen dilakukan terhadap 60 subjek dengan pendekatan studi eksperimental terhadap tiga kelompok, dimana setiap kelompok terdapat 20 subjek. Seluruh subjek yang dilibatkan dalam studi eksperimen diambil dari subjek yang terlibat dalam studi survey. Kajian eksperimental ini dilakukan untuk mendalami perilaku berbohong melalui indikator denyut jantung, getaran suara, dan waktu reaksi subjek. Denyut jantung yang dianalisis berdasarkan rata-rata heart-rate dari awal mulai sampai selesainya eksperimen dan heart-rate saat menjawab pertanyaan.

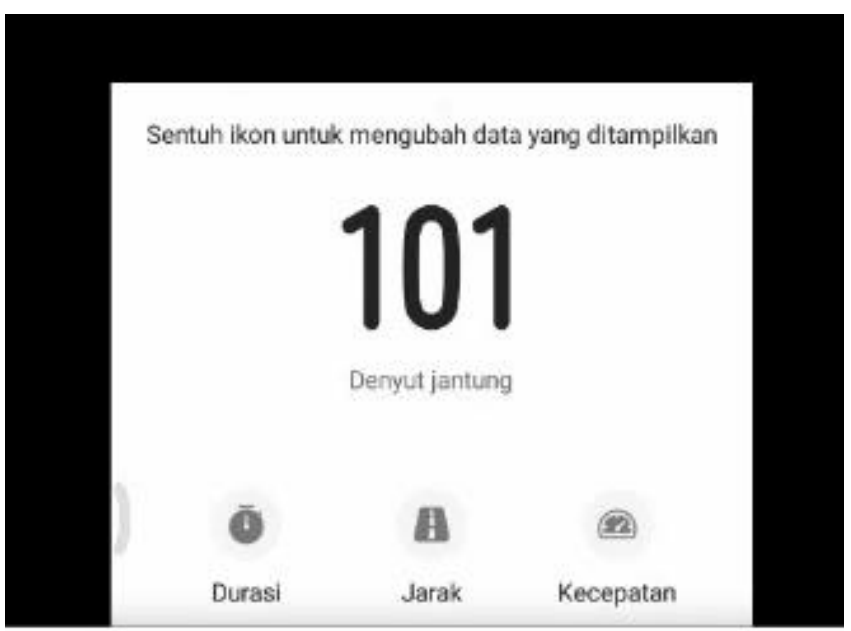

Sumber: Hasil Penelitian (2020)

Gambar 3. Alat ukur Heart Rate menggunakan wrist band

Ada pula getaran suara yang dianalisis berdasarkan besaran suara desibel (db) (diambil dari fitur amplifikasi untuk melihat suara desibel awal) dan bentuk gelombang suara. kemudian waktu reaksi subjek akan dianalisis berdasarkan waktu lamanya subjek dalam memberikan jawaban. 
Tabel 7. Hasil Heart-rate

\begin{tabular}{cccccc}
\hline Kelompok & N (Subjek & $\begin{array}{c}\text { Skor HR } \\
\text { saat } \\
\text { menjawab }\end{array}$ & Signifikansi & HR Rerata & Signifikansi \\
\hline Bohong & 20 & 43,58 & & 40,08 & \\
Jujur & 20 & 24,50 & 0,000 & 31,25 & 0,001 \\
Netral & 20 & 23,43 & & 20,18 & \\
\hline
\end{tabular}

Sumber: Hasil Pengolahan Data (2020)

Hasil dari tabel 7 memperlihatkan bahwa subjek dari ketiga kelompok (berbohong, jujur, dan netral) masing-masing terdapat 20 subjek. Dapat dilihat bahwa rata-rata skor heart-rate pada kelompok berbohong saat menjawab yaitu 43,58 dan heart-rate rata-rata keseluruhan yaitu 40,08. Pada kelompok jujur terlihat bahwa rata-rata skor heart-rate subjek pada saat menjawab yaitu sebesar 24,50 dan heart-rate rata-rata keseluruhan sebesar 31,25 . Pada kelompok netral dapat dilihat bahwa skor heart-rate pada saat subjek menjawab yaitu 23,43 dan heart-rate rata-rata keseluruhan yaitu 20,18. Kemudian dari tabel diatas dapat dilihat juga adanya nilai Signifikansi pada Skor Heart-rate saat menjawab sebesar sig $=0,000<0,05$, dan ada juga nilai signifikansi pada Heart-rate rata-rata keseluruhan sebesar sig=0,001<0,05. Hasil uji analisis memperlihatkan bahwa ketiga kelompok memiliki perbedaan berdasarkan heart-rate saat menjawab dan heart-rate rata-rata keseluruhan. Subjek pada kelompok berbohong memiliki nilai heart-rate saat menjawab lebih besar daripada kelompok jujur dan kelompok netral. Hal ini sejalan dengan hasil penelitian terdahulu yang menyatakan bahwa individu dengan tingkat kebohongan lebih tinggi akan menghasilkan heart rate yang tinggi juga (Duran et al., 2018). Begitu juga pada nilai heart-rate rata-rata keseluruhan, kelompok berbohong memiliki nilai heart-rate rata-rata keseluruhan lebih besar daripada kelompok jujur dan netral. Selanjutnya analisis dilakukan untuk melakukan uji beda suara berdasarkan tiga kelompok eksperimen.

Tabel 8. Hasil Getaran Suara

\begin{tabular}{cccccc}
\hline Kelompok & N (Subjek) & $\begin{array}{c}\text { Amplifikasi } \\
\text { Suara (db) }\end{array}$ & Signifikansi & $\begin{array}{c}\text { Rata-Rata } \\
\text { Pola } \\
\text { Gelombang }\end{array}$ & Signifikansi \\
\hline Bohong & 20 & 33,08 & & M & \\
Jujur & 20 & 35,45 & 0,05 & M & 0,06 \\
Netral & 20 & 22,98 & & W & \\
\hline
\end{tabular}

Sumber: Hasil Pengolahan Data (2020)

Hasil tabel 8 memperlihatkan subjek pada kelompok berbohong memiliki rata-rata suara (db) sebesar 33,08 db dengan rata-rata pola gelombang suara berbentuk M. Pada kelompok jujur dapat dilihat rata-rata suara ( $\mathrm{db}$ ) sebesar $35,45 \mathrm{db}$ dengan bentuk pola gelombang ratarata berbentuk M. Kemudian pada kelompok netral terlihat rata-rata suara (db) sebesar 22,98 $\mathrm{db}$ dengan bentuk gelombang suara berbentuk W. Setiap kelompok terlihat memiliki nilai signifikansi sebesar $\mathrm{sig}=0,05$ berdasarkan suara $(\mathrm{db})$. Sedangkan berdasarkan bentuk gelombang pada setiap kelompok, terdapat nilai signifikansi sebesar sign $=0,06>0,05$. Hasil uji analisis memperlihatkan bahwa masing-masing kelompok tidak memiliki perbedaan yang signifikan terhadap bentuk pola gelombang suara. Sedangkan masing-masing kelompok terhadap suara $(\mathrm{db})$ terlihat memiliki perbedaan yang signifikan. Hasil ini sama dengan penelitian sebelumnya yang menyatakan jika analisis suara pada kelompok eksperimen memiliki perbedaan (Villar et al., 2013). 
Namun pada penelitian sebelumnya individu yang berbohong memiliki decibel suara lebih tinggi daripada individu yang jujur, hal ini disebabkan karena individu yang berbohong merasa harus lebih percaya diri dengan mengeluarkan suara lebih tinggi agar tidak cemas jika sewaktu-waktu ketahuan berbohong (Vrij, 2008). Hasil menunjukan kelompok jujur memiliki suara (db) lebih besar dibandingkan kelompok berbohong dan kelompok netral (Patrick, 2018). penelitian ini juga melakukan analisis terhadap data reaction time. Data dapat terlihat pada tabel 9.

Tabel 9. Hasil Waktu Reaksi

\begin{tabular}{cccc}
\hline Kelompok & N (Subjek & $\begin{array}{c}\text { Mean Rank Durasi } \\
\text { Waktu }\end{array}$ & Signifikansi \\
\hline Bohong & 20 & 28,83 & \\
Jujur & 20 & 31,18 & 0,853 \\
Netral & 20 & 31,50 & \\
\hline Hasil Pengolahan Data (2020) & &
\end{tabular}

Sumber: Hasil Pengolahan Data (2020)

Tabel 9 memperlihatkan subjek pada kelompok berbohong memiliki nilai mean rank durasi waktu sebesar 28,83 , lalu dapat dilihat juga nilai mean rank durasi waktu pada kelompok jujur sebesar 31,18 , kemudian pada kelompok netral terdapat nilai mean rank durasi waktu sebesar 31,50. Adapun nilai signifikansi waktu reaksi terhadap kelompok eksperimen sebesar $0,853>0,05$. Hasil ini menunjukan bahwa tidak ada perbedaan yang signifikan pada waktu reaksi terhadap kelompok eksperimen. Temuan ini berbanding terbalik dengan penelitian Suchotzki. Pada penelitiannya ditemukan bahwa kelompok berbohong lebih membutuhkan waktu dalam menjawab pertanyaan (Suchotzki et al., 2017). Hasil yang beda tersebut, didasarkan pada perbedaan pemberian perlakuan pada subjek eksperimen. Dalam penelitiannya, subjek tidak diberikan pengkondisian, dalam artian subjek eksperimen bebas memberikan jawaban apapun (berbohong atau jujur), selain itu studi eksperimen dilakukan sebanyak 20 kali pengambilan data. Penelitian ini juga melakukan uji beda kepada kelompok eksperimen terhadap gerakan mata ketika menjawab sebuah pertanyaan.

Tabel 10. Hasil Gerak Mata

\begin{tabular}{ccccc}
\hline Kelompok & N (Subjek & $\begin{array}{c}\text { Arah Gerak } \\
\text { Mata }\end{array}$ & $\begin{array}{c}\text { Mean Rank } \\
\text { Gerak Mata }\end{array}$ & Signifikansi \\
\hline Bohong & 20 & Center & 28,68 & \\
Jujur & 20 & Center & 34,53 & 0,286 \\
Netral & 20 & Center & 28,30 & \\
\hline
\end{tabular}

Sumber: Hasil Pengolahan Data (2020)

Analisis gerak mata yang dilakukan pada penelitian ini faktanya membuktikan bahwa gerak mata subjek pada saat menjawab (baik secara bohong atau jujur) tidak memiliki perbedaan yang signifikan $(0,286>0,05)$. Temuan ini juga menandakan bahwa gerak mata tidak bisa dipakai untuk mendeteksi kebohongan. Hasil ini juga bisa dilihat pada kolom Arah gerak mata, terlihat bahwa ketiga kelompok sama-sama menggerakan mata ke center (titik tengah) pada saat menjawab, baik pada saat bohong atau pada saat jujur. Temuan ini sejalan dengan penelitian sebelum nya yang dilakukan oleh Wiseman, penelitian ini menemukan hasil bahwa gerak mata tidak memiliki perbedaan yang signifikan antara kelompok berbohong dan kelompok jujur (Wiseman et al., 2012).

Penelitian yang dijelaskan oleh Wiseman mengemukakan bahwa gerak mata tidak dapat dipakai untuk menganalisis antara subjek yang berbohong dan yang jujur karena memiliki keterbatasan ecological validity. Dalam hal ini desain eksperimen belum memperhatikan secara ketat mengenai keadaan natural kondisi saat eksperimen berlangsung (Wiseman et al., 2012). Dalam studi eksperimen ini, subjek diminta untuk masuk kedalam beberapa kelompok, sehingga subjek dikondisikan agar sesuai dengan kelompoknya tersebut. hal ini mengakibatkan kondisi naturalnya menurun (Schuetze \& Zeskind, 2001). 


\section{Kesimpulan}

Perilaku berbohong dapat dibahas melalui cara seseorang dalam memantau tampilan dirinya. Dalam hal ini self-monitoring dapat dijadikan sebagai anteseden untuk variabel perilaku berbohong, sebagai variabel yang dapat memberikan pengaruh terhadap perilaku berbohong. Berbeda hasilnya dengan kemampuan verbal, ternyata tidak memiliki hubungan dengan perilaku berbohong. Hal ini disebabkan karena keadaan kemampuan verbal subjek penelitian varian skornya berada pada tingkatan yang tidak tinggi. Tetapi saat self-monitoring dan kemampuan verbal pengaruhnya terhadap perilaku berbohong secara bersamaan, ternyata dapat mempengaruhi perilaku berbohong. Penelitian selanjutnya perlu melakukan kajian kepada subjek yang memiliki kapasitas kemampuan verbal yang lebih tinggi, dan juga dapat memfokuskan kajian kepada mekanisme verbal monitoring. Fenomena mengenai perilaku berbohong dapat diilihat melalui beberapa indikatornya. Penelitian berhasil mendapatkan fakta bahwa denyut jantung dan suara (db) dapat dijadikan sebagai indikator untuk membedakan antara orang-orang pada tiga kelompok penelitian. Diantara subjek yang diminta untuk jujur, berbohong, dan netral ditemukan terjadinya perbedaan dalam hal denyut jantung dan suara. Tetapi dua indikator yang lainnya (reaction time dan gerak mata) tidak ditemukan adanya perbedaan. Melalui peralatan yang digunakan dalam penelitian ini tidak berhasil mendapatkan adanya perbedaan reaction time dan gerakan mata. Penyebab yang paling mungkin adalah karena mekanisme pengkondisian kurang natural, karena kebohongan atau kejujuran subjek berdasarkan permintaan seting penelitian (tidak natural). Temuan ini mengindikasikan bahwa penelitian selanjutnya perlu menyusun desain yang natural, bukan kebohongan yang dipaksakan (memperhatikan ecological validity).

\section{Ucapan Terima Kasih}

Terimakasih kami sampaikan kepada pihak terkait dalam hal ini DRPM dan pihak lainnya karena sudah memberikan dukungan dan kesempatan untuk melaksanakan penelitian sesuai dengan tema yang dipilih dalam penelitian ini.

\section{Daftar Pustaka}

Abouelenien, M., Pérez-Rosas, V., Zhao, B., Mihalcea, R., \& Burzo, M. (2017). Gender-based multimodal deception detection. Proceedings of the ACM Symposium on Applied Computing, Part F1280, 137-144. https://doi.org/10.1145/3019612.3019644

Azwar, S. (2017). Penyusunan Skala Psikologi. Yogyakarta: Pustaka Pelajar.

Borza, D., Itu, R., \& Danescu, R. (2018). In the eye of the deceiver: Analyzing eye movements as a cue to deception. Journal of Imaging, 4(10). https://doi.org/10.3390/jimaging4100120

Burgoon, J. K., Buller, D. B., \& Floyd, K. (2001). Does Participation Affect Deception Success? 27(4), 503-534.

Critchley, H. D., \& Garfinkel, S. N. (2017). Interoception and emotion. Current Opinion in Psychology, 17, 7-14. https://doi.org/10.1016/j.copsyc.2017.04.020

Croson, R., \& Gneezy, U. (2009). Gender Differences in Preferences. 448-474.

Dreber, A., \& Johannesson, M. (2008). Gender differences in deception. Economics Letters, 99(1), 197-199. https://doi.org/10.1016/j.econlet.2007.06.027

Duran, G., Tapiero, I., \& Michael, G. A. (2018). Resting heart rate: A physiological predicator of lie detection ability. Physiology and Behavior, 186, 10-15. https://doi.org/10.1016/j.physbeh.2018.01.002

Ellis, A., \& Beattie, G. (2017). The Psychology of Language and Communication. Routledge.

Flynn, F. J., \& Ames, D. R. (2006). What's good for the goose may not be as good for the gander: The benefits of self-monitoring for men and women in task groups and dyadic conflicts. Journal of Applied Psychology, 91(2), 272-281. https://doi.org/10.1037/00219010.91.2.272

Hogue, M., Levashina, J., \& Hang, H. (2016). Will I Fake It? The Interplay of Gender, Machiavellianism, and Self- monitoring on Strategies for Honesty in Job Interviews Will I Fake It? The Interplay of Gender, Machiavellianism, and Self-monitoring on Strategies for Honesty in Job Interviews. (November). https://doi.org/10.1007/s10551-012-1525-x

JR, joseph j. bango. (2003). POLY GRAPH UTILIZING MEDICAL IMAGING. 1(19).

Marshall, E., \& Samuels, P. (2017). Checking normality for parametric tests One. 1-4. Retrieved from https://www.sheffield.ac.uk/polopoly_fs/1.579191!/file/stcp-karadimitriou-normalR.pdf 
Meijer, E. H., Verschuere, B., Gamer, M., Merckelbach, H., \& Ben-Shakhar, G. (2016). Deception detection with behavioral, autonomic, and neural measures: Conceptual and methodological considerations that warrant modesty. Psychophysiology, 53(5), 593-604. https://doi.org/10.1111/psyp.12609

Nelson, R. (2015). Scientific Basis for Polygraph Testing Raymond Nelson. Polygraph, 44(1), 245.

Patrick, wendy I. (2018, April 19). Sound Too Good to Be True ? Recognizing the Sound of a Lie. Psychology Today, pp. 1-4.

Saxe, L., \& Ben-Shakhar, G. (1999). Admissibility of polygraph tests: The Application of Scientific Standards Post-Daubert. Psychology, Public Policy, and Law, 5(1), 203-223. https://doi.org/10.1037/1076-8971.5.1.203

Schiller, N. O. (2005). Twenty First Century Psycholinguistic (A. Cutler, Ed.). New Jersey: lawrance Erlbaum Associate.

Schuetze, P., \& Zeskind, P. S. (2001). What is Ecological Validity? A dimensional analysis. (773573598). https://doi.org/10.1207/S15327078IN0204

Sharma, M. D., \& Bewes, J. (2011). J ournal of Learning Design Self-monitoring : Confidence , academic achievement and gender differences in physics. 4(3), 1-13.

Shibley, J., \& Marcia, C. (1988). Gender Differences in Verbal Ability: A Meta-Analysis.

Snyder, Mark, U. M. (1974). Self-Monitoring of Expressive Behavior. Journal of Personality and Social Psychology, 30(4), 526-537. https://doi.org/<a data-auto="link" href="javascript:_doLinkPostBack(",'ss DI\%20\%2210.1037\%2Fh0037039\%22\%7C\%7 Csl rl',");" - title="Search for 10.1037/h0037039" id=“link10.1037h0037039">10.1037/h0037039</a>

Suchotzki, K., Verschuere, B., Bockstaele, B. Van, Ben-Shakhar, G., \& Crombez, G. (2017). Lying takes time: A meta-analysis on reaction time measures of deception. Psychological Bulletin, 143(4), 428-453. https://doi.org/10.1037/bul0000087

Sullivan, S., Campbell, A., Hutton, S. B., \& Ruffman, T. (2017). What's good for the goose is not good for the gander: Age and gender differences in scanning emotion faces. 72(3), 441-447. https://doi.org/10.1093/geronb/gbv033

Talwar, V., \& Lee, K. (2008). Social and cognitive correlates of children's lying behavior. Child Development, 79(4), 866-881. https://doi.org/10.1111/j.1467-8624.2008.01164.x

Villar, G., Arciuli, J., \& Paterson, H. (2013). Vocal Pitch Production during Lying: Beliefs about Deception Matter. Psychiatry, Psychology and Law, 20(1), 123-132. https://doi.org/10.1080/13218719.2011.633320

Vrij, A. (2008). Detecting Lies and Deceit (Pitfalls and Oppurtinity) (2nd ed.). British.

Walczyk, J. J., Schwartz, J. P., Clifton, R., Adams, B., Wei, M., \& Zha, P. (2005). Lying personto-person about life events: A cognitive framework for lie detection. Personnel Psychology, 58(1), 141-170. https://doi.org/10.1111/j.1744-6570.2005.00484.x

Wiseman, R., Watt, C., Brinke, L., Porter, S., Couper, S. L., \& Rankin, C. (2012). The eyes don't have it: Lie detection and neuro-linguistic programming. PLOS ONE, 7(7), 1-5. https://doi.org/10.1371/journal.pone.0040259

Zuckerman, M., \& Driver, R. E. (1985). Telling Lies: Verbal and nonverbal Correlates of Deception (pp. 129-130). pp. 129-130. 